\title{
PEMANFAATAN KULIT BUAH KAKAO DAN KULIT BUAH PISANG YANG DIFERMENTASI BERBAGAI BIOAKTIVATOR TERHADAP PERFORMANS KAMBING KACANG JANTAN LEPAS SAPIH
}

\author{
Utilization of Fermented Cacao Pod and Banana Peel with Various Bio-Activator on \\ Performances of Weaning Males Kacang Goat
}

\author{
Oswald Agasy $^{1}$, Tri Hesti Wahyuni ${ }^{2}$ dan Armyn Hakim Daulay ${ }^{2}$ \\ 1. Mahasiswa Program Studi Peternakan Fakultas Pertanian Universitas SumateraUtara \\ 2. Staf Pengajar Program Studi Peternakan Fakultas Pertanian Universitas Sumatera Utara
}

\begin{abstract}
Utilization of Cacao Pod and Bananas Peel as animal feed can be maximized through the processed fermentation. The research aims to determine the effect of the utilization of cacao pod and bananas peel fermented on the performances of Weaning Males Kacang Goat. The research was conducted in the Laboratory Animal Production, Agriculture Faculty, University of Sumatera Utara from September until November 2014. This study used 20 weaning male kacang goats with initial body weights $10,47 \pm 0,28 \mathrm{~kg}$ and experimental design used completely randomize design (CRD), which consists of 4 treatments and 5 replications. The treatments were complete rations containing 20\% Cacao Pod $+30 \%$ Banana Peel without fermentation (P0), fermented by MOL (P1), fermented by buffalo rumen bacterial isolates (P2), and fermented by starbio (P3). The research showed that the average feed consumption (g/head/week) for treatments $P 0 ; P 1 ; P 2 ;$ and P3 were 2844,63; 2419,61; 2420,72; and 2641,93 respectively. The Average Daily Gain (ADG) g/head/day as 47,66; 44,52; 41,31; and 55,59 respectively, and the Feed Conversion Ratio (FCR) such as 7,53; 9,67; 6,06; and 6,68 respectively. Treatment did not significantly diffrent on feed consumption, Average Daily Gain (ADG), and the Feed Conversion Ratio ( FCR) (P>0,05). The conclusion of this research that utilization of various bio-activator on the cacao pod and banana peel can be used as feed of Weaning Males Kacang Goat.
\end{abstract}

Keywords: Kacang Goats Males, Cacao Pod, Banana peel, bio-activator and performances.

\begin{abstract}
ABSTRAK
Pemanfaatan kulit buah kakao dan kulit buah pisang sebagai pakan ternak dapat dimaksimalkan melalui proses fermentasi. Penelitian ini bertujuan untuk mengetahui pengaruh pemanfaatan kulit buah kakao dan kulit buah pisang yang difermentasi terhadap performans kambing kacang jantan lepas sapih. Penelitian dilaksanakan di Laboratorium Biologi Ternak Program Studi Peternakan, Fakultas Pertanian, Universitas Sumatera Utara selama 3 bulan, dimulai bulan September 2014-November 2014. Penelitian ini menggunakan 20

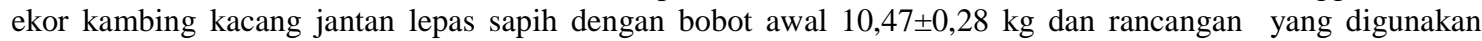
adalah rancangan acak lengkap (RAL) yang terdiri atas 4 perlakuan dan 5 ulangan. Perlakuan terdiri atas ransum komplit yang mengandung $20 \%$ kulit buah kakao $+30 \%$ kulit buah pisang tanpa fermentasi (P0), Ransum komplit yang difermentasi MOL (P1), Ransum komplit mengandung yang difermentasi isolat bakteri rumen kerbau (P2), Ransum komplit yang di fermentasi starbio (P3). Hasil penelitian menunjukkan bahwa Rataan dari masing-masing perlakuan yaitu, P0, P1, P2, dan P3 berturut-turut untuk rataan konsumsi pakan adalah 2844,63; 241,61; 2420,72; dan 2641,93 g/ekor/minggu, rataan pertambahan bobot badan adalah 333,67; 311,67; 289,17; dan 389, 17 g/ekor/minggu dan rataan konversi pakan adalah 7,53; 9,67; 6,06; dan 6,68. Kambing kacang yang diberi perlakuan menunjukkan perbedaan yang tidak nyata terhadap konsumsi pakan, pertambahan bobot badan dan konversi pakan $(\mathrm{P}>0,05)$. Kesimpulan dari hasil penelitian ini adalah bahwa penggunaan berbagai bioaktivator dalam fermentasi kulit buah kakao dan kulit buah pisang dapat digunakan sebagai pakan kambing kacang jantan lepas sapih.
\end{abstract}

Kata kunci: Kambing kacang, kulit buah kakao, kulit buah pisang, bioaktivator dan performans. 


\section{PENDAHULUAN}

Kambing kacang adalah ras unggulan kambing yang pertama kali dikembangkan di Indonesia. Kambing kacang memiliki keunggulan yang jarang dimiliki jenis kambing lainnya. Tingkat daya adaptasinya terhadap lingkungan sekitar yang baik, sehingga kambing kacang relatif tahan terhadap penyakit. Selain itu, kambing kacang memiliki tingkat reproduksi yang lebih tinggi sehingga cepat dikembangbiakkan. Kambing kacang adalah kambing lokal, merupakan kambing khas Indonesia dan Malaysia. Kambing kacang merupakan kambing tipe pedaging baik kambing kacang jantan maupun kambing kacang betina.

Badan kambing kacang relatif lebih kecil dari jenis kambing lainnya. Memiliki kepala yang kecil. Telinga tegak, mempunyai bulu yang lurus dan pendek. Bulu kambing pendek untuk seluruh tubuhnya, namun bulu panjang pada ekor dan dagu. Kambing kacang jantan memiliki bulu yang panjang sebatas garis leher sampai pundak, punggung hingga ekor dan pantat. Biasanya hanya memiliki warna tunggal, hitam, putih, coklat atau kombinasi dari ketiga warna tersebut. Betina maupun jantan memiliki tanduk yang pendek. Berat badan kambing jantan dewasa bisa mencapai $35 \mathrm{~kg}$, dan kambing betina dewasa nya bisa mencapai $30 \mathrm{~kg}$. Tinggi kambing jantan berkisar $60-70 \mathrm{~cm}$, dan yang betina hingga $50 \mathrm{~cm}$.

Kulit buah pisang memiliki banyak manfaat, dapat dijadikan berbagai macam produk olahan yang dapat dimanfaatkan oleh manusia, seperti nata dari kulit pisang dan mie dari kulit pisang. Selain menjadi produk olahan, kulit pisang juga dapat langsung diberikan pada ternak ruminansia, seperti sapi dan kambing. Banyak peternak menggunakan kulit pisang sebagai bahan pakan pelengkap bagi ternaknya.

Sayangnya, kulit pisang tidak dapat diberikan langsung pada ternak non ruminansia seperti kelinci dan ternak unggas. Kulit pisang ini harus mengalami proses terlebih dahulu agar kulit pisang ini dapat dimanfaatkan bagi semua jenis ternak.

Limbah kulit buah kakao (KBK) merupakan pakan yang potensial karena tersedia sepanjang tahun, mudah diperoleh dan mengandung nutrisi tinggi. Buah kakao (pode) terdiri atas $70-80 \%$ kulit dan plasenta yang merupakan limbah, selebihnya adalah biji. Dalam 1 hektar areal pertanaman kakao produktif dapat menghasilkan limbah kulit buah segar sebanyak 5 ton/ha/tahun, atau setara dengan $812 \mathrm{~kg}$ tepung limbah.

Kulit buah kakao dengan kandungan protein kasar sebesar 6-9\% sangat baik dimanfaatkan sebagai pakan ternak ruminansia. Pemanfaatan KBK sebagai pakan, secara 
otomatis menciptakan kondisi lahan pertanaman kakao menjadi bersih dan dapat menekan serangan hama dan penyakit.

Limbah yang digunakan sebagai bahan pakan ternak masih memerlukan proses pengolahan guna meningkatkan kualitas nutrisi bahan pakan. Pengolahan limbah sebagai bahan pakan pakan dapat dilakukan dengan berbagai cara, salah satunya dengan teknik fermentasi. Fermentasi bertujuan untuk menghilangkan zat anti nutrisi yang terdapat pada limbah, meningkatkan kualitas gizi dan memperbaiki tekstur bahan pakannya.

Oleh karena itu dalam penggunaan kulit buah kakao dan kulit buah pisang ini perlu dilakukan fermentasi. Fermentasi yang dilakukan dengan menggunakan Mikroorganisme Lokal (MOL), starbio, dan cairan rumen.

\section{BAHAN DAN METODE PENELITIAN}

\section{Tempat dan Waktu Penelitian}

Penelitian ini akan dilaksanakan di Laboratorium Bahan Pakan Ternak dan Formula Ransum Program Studi Peternakan Fakultas Pertanian Universitas Sumatera. Penelitian ini dilakukan selama 3 bulan dimulai dari bulan September sampai dengan bulan November 2014.

\section{Bahan dan Alat Penelitian}

\section{Bahan}

Bahan yang digunakan yaitu kambing kacang jantan lepas sapih sebanyak 20 ekor dengan rataan bobot badan awal $10.47 \pm 0.28 \mathrm{~kg}$, ransum komplit yang terdiri dari dedak padi, bungkil kedele, onggok, ampas tahu, molases, mineral, garam dan urea. Kulit buah kakao dan kulit buah pisang yang dimanfaatkan sebagai pakan, MOL sebagai bioaktivator, isolat rumen serta starbio sebagai bioaktivator pembanding, rodalon sebagai desinfektan dan air minum yang diberi secara ad libitum serta obat-obatan berupa kalbazen (obat cacing) dan anti bloat (obat kembung).

\footnotetext{
Alat

Alat yang digunakan yaitu kandang 20 unit dengan ukuran 1 x $0.5 \mathrm{~m}$, ember sebagai tempat pakan dan tempat minum masing-masing 20 buah, timbangan untuk menimbang bobot hidup berkapasitas $50 \mathrm{~kg}$ dengan kepekaan $2 \mathrm{~kg}$, timbangan berkapasitas $2 \mathrm{~kg}$ dengan kepekaan 10 gr untuk menimbang pakan, grinder untuk menghaluskan bahan pakan, alat penerangan kandang, alat pembersih kandang dan alat tulis.
} 


\section{Metode Penelitian}

Metode penelitian yang digunakan adalah rancangan acak lengkap (RAL) yang terdiri dari 4 perlakuan dan 5 ulangan. Adapun susunan perlakuan yang diberikan adalah sebagai berikut:

$\mathrm{P} 0=$ Ransum komplit yang mengandung $(20 \%$ kulit buah kakao $+30 \%$ kulit buah pisang) tanpa fermentasi

$\mathrm{P} 1=$ Ransum komplit yang mengandung $(20 \%$ kulit buah kakao $+30 \%$ kulit buah pisang) fermentasi mikroorganisme lokal

$\mathrm{P} 2=$ Ransum komplit yang mengandung $(20 \%$ kulit buah kakao $+30 \%$ kulit buah pisang) fermentasi isolat bakteri rumen kerbau

P3 = Ransum komplit yang mengandung $(20 \%$ kulit buah kakao $+30 \%$ kulit buah pisang) fermentasi starbio

Konsentrasi atau kadar dari bioaktivator yang digunakan untuk fermentasi $1 \mathrm{~kg}$ bahan pakan adalah $0,3 \%$ per $\mathrm{kg}$ bahan pakan.

\section{Parameter Penelitian}

\section{Konsumsi Pakan}

Data konsumsi pakan yang akan diperoleh dengan cara penimbangan ransum yang diberikan, kemudian dikurangi dengan penimbangan sisa ransum, dengan perhitungan (Harris, 1970): Konsumsi Pakan (BK) : $\quad$ Pakan Awal (BK) - Pakan sisa (BK)

\section{Pertambahan Bobot Badan (g)}

Data pertambahan bobot badan diperoleh dengan cara penimbangan setiap minggu yang merupakan selisih antara penimbangan bobot badan akhir dengan penimbangan bobot awal persatuan waktu (g/minggu), dengan perhitungan (Soeparno, 1992):

Pertambahan Bobot Badan $(\mathrm{PBB})=$ Bobot Badan Akhir - Bobot Badan Awal

\section{Konversi Pakan}

Data Konversi pakan dihitung setiap minggu dengan cara membandingkan jumlah ransum (gram) yang dikonsumsi dengan pertambahan bobot badan (gram) setiap minggu, dengan perhitungan (Anggorodi, 1994) :

$$
\text { Konversi Ransum }=\underline{\text { Konsumsi Ransum }}
$$

\section{Susunan ransum percobaan penelitian}

\section{PBB}

Adapun susunan ransum percobaan penelitian adalah seperti dibawah ini. 
Tabel 1. Susunan ransum percobaan

\begin{tabular}{lrrrr}
\hline Nama Bahan & P0 & P1 & P2 & P3 \\
\cline { 2 - 5 } Pod kakao (\%) & 20,00 & 20,00 & 20,00 & 20,00 \\
Kulit pisang (\%) & 30,00 & 30,00 & 30,00 & 30,00 \\
dedak padi (\%) & 3,07 & 3,07 & 3,07 & 3,07 \\
bungkil kedele (\%) & 8,43 & 8,43 & 8,43 & 8,43 \\
Ampas tahu (\%) & 15,00 & 15,00 & 15,00 & 15,00 \\
Onggok (\%) & 19,70 & 19,70 & 19,70 & 19,70 \\
Molases (\%) & 3,00 & 3,00 & 3,00 & 3,00 \\
Garam (\%) & 0,15 & 0,15 & 0,15 & 0,15 \\
Mineral (\%) & 0,15 & 0,15 & 0,15 & 0,15 \\
Urea (\%) & 0,50 & 0,50 & 0,50 & 0,50 \\
\hline Total & 100,00 & 100,00 & 100,00 & 100,00 \\
\hline Nutrisi & & & & \\
TDN (\%) & 64,85 & 64,82 & 64,18 & 64,30 \\
PK (\%) & 13,52 & 14,58 & 15,08 & 15,36 \\
LK (\%) & 6,85 & 6,42 & 6,10 & 5,79 \\
SK (\%) & 17,98 & 16,50 & 16,12 & 15,58 \\
\hline
\end{tabular}

Hanafiah (2003), menyatakan model linear yang digunakan untuk rancangan acak lengkap (RAL) adalah:

$\mathrm{Y}_{\mathrm{ij}}=\mu+{ }_{\mathrm{i}}+\mathrm{ij}$

Keterangan:

$\mathrm{Y}_{\mathrm{ij}} \quad=$ Nilai pengamatan yang diperoleh dari satuan percobaan dari

perlakuan ke-i dan ulangan ke-j

$\mu \quad=$ Rataan/nilai tengah

$\sigma_{\mathrm{i}} \quad=$ Efek dari perlakuan ke- $\mathrm{i}$

ij = Pengaruh galat percobaan perlakuan ke-i dan ulangan ke-j

\section{HASIL DAN PEMBAHASAN}

\section{Konsumsi Pakan}

Konsumsi pakan diperoleh dengan cara penimbangan ransum yang diberikan, kemudian dikurangi dengan penimbangan ransum yang sisa. Dari hasil penelitian yang dilakukan, maka diperoleh rataan konsumsi pakan pada kambing kacang jantan seperti pada Tabel 2

Dari Tabel 2, dapat dilihat bahwa rataan konsumsi pakan kambing kacang jantan selama penelitian adalah 2581,72 g/ekor/minggu dengan P0 sebesar $2844.63 \mathrm{~g} / \mathrm{ekor} / \mathrm{minggu}$; P1 2419,61g/ekor/minggu; P2 sebesar 2420,72 dan P3 sebesar 2641,93 g/ekor/minggu 
dengan rataan tertinggi diperoleh pada perlakuan P0 dan terendah pada perlakuan P1. Hasil penelitian ini lebih rendah dari hasil penelitian Suparjo et al (2008) yang menggunakan KBK fermentasi pada kambing lokal jantan dengan rataan konsumsi 3,038 g/ekor/mg sampai 3,920 g/ekor/mg.

Hasil analisis ragam dapat dilihat bahwa pengaruh pemanfaatan kulit pisang dan kulit kakao yang difermentasi berbagai bioaktivator tidak berbeda nyata $(\mathrm{P}>0.05)$ terhadap konsumsi ransum. Hal ini diduga bahwa kulit kakao dan kulit pisang fermentasi tidak banyak memberikan pengaruh terhadap palatabilitas ternak kambing. Adanya pengaruh tidak berbeda nyata antar perlakuan ini diduga disebabkan oleh bentuk dan jumlah pakan antar perlakuan yang hampir sama sehingga tingkat palatabilitas ternak juga tidak berbeda secara signifikan. Hal ini sesuai dengan pernyataan Tobing (2010) yang menyatakan bahwa besar kecilnya konsumsi pakan ditentukan beberapa faktor antara lain palatabilitas, kondisi lingkungan, umur, kesehatan, tingkat produksi dan bentuk pakan. Selain itu, Devendra dan Leng (2011) menambahkan bahwa jumlah konsumsi ransum pada dasarnya tergantung pada palatabilitas serta karakteristik fisik.

\section{Pertambahan Bobot Badan}

Pertambahan bobot badan diperoleh dari pengurangan penimbangan bobot badan dengan penimbangan bobot badan sebelumnya. Hasil rataan pertambahan bobot badan kambing kacang jantan selama penelitian adalah sebagai berikut. Dari Tabel 2, dapat diketahui bahwa rataan pertambahan bobot badan kambing kacang jantan selama penelitian adalah 330.92 g/ekor/minggu. Pertambahan bobot badan terendah didapat pada perlakuan P2 sebesar 289.17 g/ekor/minggu dan tertinggi pada perlakuan P3 sebesar 389.17 g/ekor/minggu. Hasil penelitian ini jauh lebih rendah jika dibandingkan dengan hasil penelitian Suparjo et al (2011) menggunakan KBK fermentasi yang dikombinasikan dengan rumput gajah dan konsentrat pada kambing diperoleh PBB sebesar 58,95-102 g/ekor/hari atau sekitar 412,65-714 g/ekor/mg.

Sudrajat (2000) menunjukkan bahwa pertumbuhan kambing muda 45,36-48,45 g/ekor/hr. Hal ini menunjukkan bahwa pakan yang diberikan telah memenuhi kebutuhan hidup pokok dan kelebihan nutrisi digunakan untuk produksi dan pertambahan bobot badan.

Berdasarkan hasil analisis ragam, diketahui bahwa penggunaan KBK dan kulit buah pisang fermentasi memberikan pengaruh yang tidak berbeda nyata $(\mathrm{P}>0.05)$ antar perlakuan. Hal ini diduga karena konsumsi pakan yang juga tidak berbeda nyata menyebabkan 
pertambahan bobot badan juga tidak berbeda nyata. Dilihat dari kandungan protein dan TDN dari masing-masing perlakuan hampir sama diduga juga menyebabkan pertambahan bobot badan antar perlakuan tidak berbeda secara signifikan. Hal ini sesuai dengan pernyataan Parakkasi (1999) bahwa konsumsi BK dan BO ransum dapat mempengaruhi PBBH. Selain konsumsi BK dan BO dan TDN ransum juga mempengaruhi PBBH ternak. Mucra (2005) juga menjelaskan bahwa ternak yang mengkonsumsi ransum dengan kandungan za-zat makanan yang hampir sama seperti kandungan PK dan TDN akan memperlihatkan PBBH yang hampir sama.

Tabel 2. Rekapitulasi hasil penelitian pemanfaatan kulit pisang dan kulit kakao yang difermentasi berbagai bioaktivator terhadap performans kambing kacang jantan.

\begin{tabular}{cccc}
\hline Perlakuan & $\begin{array}{c}\text { Konsumsi Pakan } \\
\text { (g/ekor/mg) }\end{array}$ & $\begin{array}{c}\text { Pertambahan Bobot Badan } \\
(\mathrm{g} / \mathrm{ekor} / \mathrm{mg})\end{array}$ & $\begin{array}{c}\text { Konversi } \\
\text { Pakan }\end{array}$ \\
\hline P0 & $2844,63^{\mathrm{tn}} \pm 829,07$ & $333,67^{\mathrm{tn}} \pm 159,93$ & $7,53^{\mathrm{tn}} \pm 2,46$ \\
P1 & $2419,61^{\mathrm{tn}} \pm 643,63$ & $311,67^{\mathrm{tn}} \pm 160,32$ & $9,67^{\mathrm{tn}} \pm 8,40$ \\
P2 & $2420,72^{\mathrm{tn}} \pm 418,14$ & $289,17^{\mathrm{tn}} \pm 94,81$ & $6,06^{\mathrm{tn}} \pm 1,13$ \\
P3 & $2641,93^{\mathrm{tn}} \pm 596,38$ & $389,17^{\mathrm{tn}} \pm 192,88$ & $6,68^{\text {th }} \pm 3,54$ \\
\hline Rataan & $2581,72^{\mathrm{tn}} \pm 424,15$ & $330,92^{\mathrm{tn}} \pm 130,93$ & $7,48^{\mathrm{tn}} \pm 2,64$ \\
\hline
\end{tabular}

Keterangan : tn $=$ Tidak berbeda nyata

\section{Konversi Pakan}

Data konversi pakan dihitung setiap minggu dengan cara membandingkan jumlah ransum (gram) yang dikonsumsi dengan pertambahan bobot badan (gram) setiap minggu. Dari Tabel 2 dapat dilihat rataan konversi pakan selama penelitian adalah 7,48. Rataan konversi masing-masing perlakuan P0 sebesar 7,53; P1 sebesar 9,67; P2 sebesar 6,06 dan P3 sebesar 6,68 yang mana rataan konversi terendah diperoleh pada perlakuan P2 dan tertinggi pada perlakuan $\mathrm{P} 1$.

Hasil penelitian ini lebih tinggi jika dibandingkan dengan hasil penelitian Kamalidin et al (2012) yang menggunakan KBK fermentasi pada performans domba dengan konversi ransum berturut-turut adalah K: 4,80; NF: 5,21: dan F: 6,27. Hasil konversi ransum pada penelitian ini mendekati efisien karena Hadi (2008) mengemukakan bahwa semakin kecil angka konversi pakan, maka semakin efisien pemanfaatan ransum oleh ternak dengan angka konversi 5-6.

Hasil analisis sidik ragam menunjukan bahwa pemberian kulit buah kakao dan kulit pisang dalam ransum pada kambing kacang jantan memberikan pengaruh yang tidak berbeda nyata $(\mathrm{P}>0,05)$ terhadap konversi pakan. Konversi pakan antar perlakuan tidak berbeda nyata, 
karena konsumsi bahan kering dan pertambahan bobot badan yang dihasilkan juga tidak berbeda nyata.

Ini menunjukkan bahwa efisiensi penggunaan dan kualitas pakan hampir sama pada setiap perlakuan. Hal ini sesuai dengan pernyataan Martawidjaya et al., (1999), yang menyatakan kualitas pakan menentukan konversi pakan. Pakan yang berkualitas baik dapat menghasilkan pertambahan bobot badan yang tinggi. Penggunaan pakan akan semakin efisiensi bila jumlah pakan yang dikonsumsi minimal namun menghasilkan pertambahan bobot badan yang tinggi.

\section{KESIMPULAN}

Kesimpulan dari hasil penelitian ini adalah bahwa penggunaan berbagai bioaktivator dalam fermentasi kulit buah kakao dan kulit buah pisang dapat digunakan sebagai pakan kambing kacang jantan lepas sapih.

\section{DAFTAR PUSTAKA}

Anggorodi, R. 1994. Ilmu Makanan Ternak umum. Cetakan ke-5. Gramedia Pustaka Utama. Jakarta

Devendra. C and R.A.Leng. 2011. Feed Resources For Animalsin Asia; issues,strategies for use, intensification and integrationfor Increased Productivity. Asian-Aust. J.Anim.Sci 24 (3):303-321.

Hadi. R.F. 2008. Pengaruh emberian suplementasi protein terhadap konsumsi dan kecernaan nutrien pakan basal jerami kacang tanah. Skripsi Sarjana Peternakan. Fakultas Peternakan. Universitas Gadjah Mada. Yogyakarta.

Hanafiah, K.A. 2003. Rancangan Percobaan Teori dan Aplikasi, PT.Raja Grafindo Persada. Jakarta

Harris, L.E. 1970. Nutrition Research Technique for Domestic and Wild Animal. Vol 1. An International Record System and Procedur for Analyzing Sample. Animal Science Departement. Utah State University. Logan. Utah

Kamalidin, Ali Agus, dan I Gede Suparta Budisatria . 2012. Performa Domba Yang diberi Complet Feed Kulit Buah Kakao Terfermentasi.Buletin Peternakan Vol.36 (3): 162-16.

Martawidjaya, M. B. Setiadi dan S. S. Sitorus, 1999. Pengaruh Tingkat Protein Energi Ransum terhadap kinerja Produksi Kambing Kacang Muda. Balai Penelitian Ternak, Jurnal Ilmu Ternak dan Veteriner.

Mucra . DA. 2005. Pengaruh Pemakaian Pod Coklat Sebagai Pengganti Jagung Dalam Ransum Terhadap Pertambahan Bobot Badan dan Efisiensi Penggunaan Ransum Pada Sapi Brahman Cross. J. Peternakan. 2:37-44

Parakkasi, A., 1999. Ilmu Nutrisi dan Makanan Ternak Ruminansia, UI Press, Jakarta.

Soeparno, 1992. Ilmu Teknologi Daging. Gadjah Mada University Press. Yogyakarta.

Sudrajat, D. 2000. Pengaruh Suplementasi Se Organik dalam Ransum Terhadap Kecernaan, Aktifitas Fermentasi dan Pertumbuhan Kambing Peranakan Etawah. Tesis, Program Pascasarjana Insitut Pertanian Bogor. Bogor. 
Suparjo, K. G. Wiryawan, E. B. Laconi, \& D. Mangunwidjaja. 2011. Performa Kambing yang diberi Kulit Buah Kakao Terfermentasi. Media Peternakan, Journal IPB. Bogor.

Tobing N.L. 2010. Pengaruh Formulasi Pakan Terhadap Kandungan Pakan Ternak Ruminansia. Publikasi Budidaya Ternak Ruminansia . Edisi I Tahun 2010. 